29 (111) K. 21

4) 奥井, 薬局, 3, 別冊 (1952)

（倚本研究の一部は去る 10 月行われた第 5 回大阪䁔造学会に於て発表した。）

（京都市立工業研究所）

\title{
Studies on Colorimetric Determination of Methanol in Ethanolic Solutoin with Chromotropic Acid
}

by Shiro Yamamura and Toshiyuki Matsuoka

(Industrial Research Laboratory of Kyoto City)

(Received Nov. 1, 1953)

\section{Summary}

The method of determining methanol in ethanolic solutions with chromotropic acid was studied witn the following satisfactory results:

1) Constant standard extinction curves of methanol were obtained under the same reaction conditions, and analytical results of methanol in unknown samples were good when based on these curves. Above all, it is worthy of notice that the color was stable in several ten hours.

2) The determination sensitivity was about 10-20 times as high as that by the fuchsin method.

\section{酒造用水の硬度測定に就て}

田 村 寛・寺 田章

緒

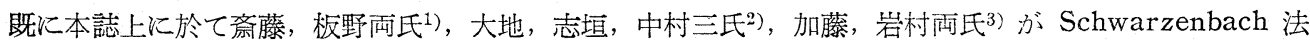
による水の硬度測定について報告されて居られるが，我々もまた本法を用いて群馬県下の酒造用水について 分析を行つたので報告する。

\section{実 験 之 部}

\section{（A）石 醶 法}

山田正一氏著釀造分析法記載の方法によつた。

\section{(B) Schwarzenbach 法}

後記の文献記載の方法によつた。全硬度測定の場合は，妨害イオンの影響をのぞくために $3 \%$ 青酸加里液 5 滴宛を滴下し, カルシウム硬度測定は指示薬ムレキサイドを用いる直接法によつた。

\section{実 験 結 果}

第一表 酒造用水の硬度測定について

\begin{tabular}{|c|c|c|c|c|c|c|c|c|}
\hline \multirow[b]{2}{*}{ 酒 造 場 } & 石䶨法 & \multicolumn{6}{|c|}{ Schwarzenbach 法 } & \multirow[b]{2}{*}{ 備 } \\
\hline & 全硬度 & 全硬度 & $\begin{array}{l}\text { カルシウ } \\
\text { ム硬度 }\end{array}$ & $\begin{array}{l}\text { マグネシ } \\
\text { ウム硬度 }\end{array}$ & $\mathrm{Ca}: \mathrm{Mg}$ & 硬度 & $\begin{array}{ll}\text { 永 } & \text { 久 } \\
\text { 硬 } & \text { 度 }\end{array}$ & \\
\hline 柿崎屋馬場酒造 ( 1 ) & 3.90 & 4.82 & 3.50 & 1.32 & $3: 1$ & - & - & \\
\hline (2) & 3.75 & 4.98 & 3.20 & 1.78 & $2: 1$ & - & - & \\
\hline 毛塚 銘 䁔 & 3.15 & 3.10 & 2.27 & 0.83 & $3: 1$ & 1.10 & 2.00 & \\
\hline 岄 村 合 名(イ) & 7.50 & 7.48 & 4.92 & 2.56 & $2: 1$ & 2.78 & 4.70 & \\
\hline$" \prime \quad(\square)$ & 5.76 & 6.10 & 4.21 & 1.89 & $2: 1$ & 3. 30 & 2.80 & \\
\hline
\end{tabular}




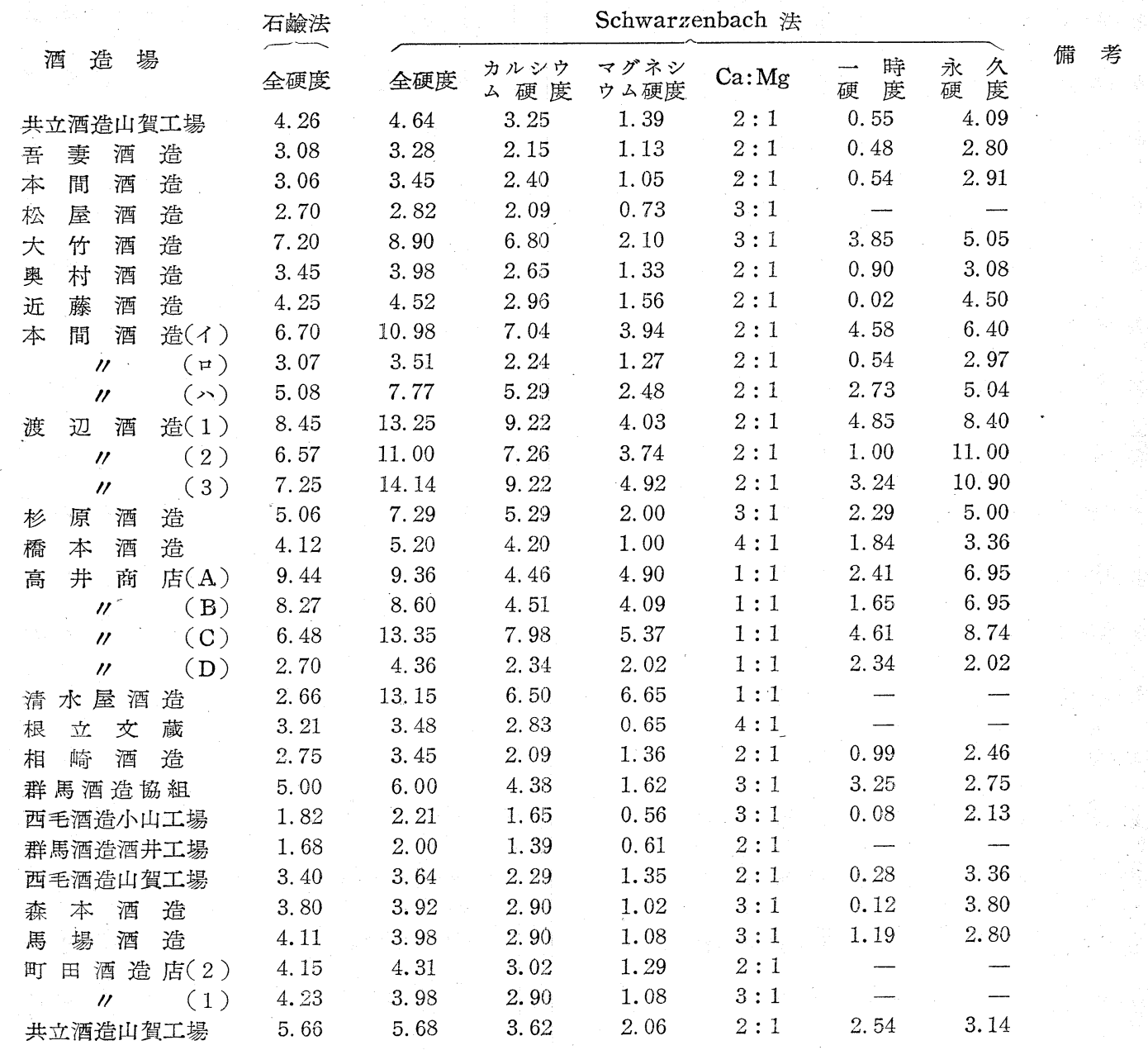

\section{考察並びに要約}

（1）群馬県下の酒造用水 39 点につき Schwarzenbach 法そ石检法によつて硬度を測定したが，Schwarzenbach 法は各酒造場に於ても容易に実施し得る正確, 迅速, 簡便, 低廉 (1 点平均 15 円かかる)な 方法であることを認めた。

（2）Schwarzenbach 法による分析值と石䌞法による分析値との差, 換言すれば石嶮法の誤差は次のよ 与な分布を示したが，誤差 0 〜 の範囲のものが 39 点中 26 点ということは石簽法の実用性を裏書きする ものである。

$$
\begin{array}{lccc}
\text { 誤差 } 0 \sim 1 \text { の間のもの } & 26 \text { 点 } & 4 \text { 誤差 } 2 \sim 3 \text { の間のもの } & 3 \text { 点 } \\
\text { "I } 1 \sim 2 & \text { " }
\end{array}
$$

（3）供試酒造用水 39 点中カルシウムとマグネシウムの含有量比は次のよ5な分布を示した。

$\begin{array}{ccrl}\text { カルシウム:マグネシウム } 4: 1 \text { のもの } & 2 \text { 点 } \\ 3: 1 & 10 / l\end{array}$

（4）所謂水の力を判断するに当つて, 石瞼法による分析値だけでなく, Schwarzenbach 法によつてカ ルシウム确度，マグネシウム硬度，一時硬度と永久硬度を測定し，更に伊藤氏(4)の提唱されるように水の電 完伝導度をも測定するならば，水の相(phase) の解析と相俟つて正鴾を射たものとなるであるら。

（5）自家の醪の醱酵状態を年々觀察して来ている酒造家たちが，征来の石鹼法による硬度では納得のい かない例も県内にあつたのであるが，こんどの試験によつてその内若干例が解明された。

終りに臨又試料その他御協力を賜わつた酒造家各位に対し，また有益な御助言を賜わつた当場高橋接師， 織茂技師に対し樑甚な謝意を表する。（群馬県醸造試験場）

交

(1) 斎藤, 板野: 日䁔協 46巻 432頁 (1951)

(3) 加藤, 岩村: 日醸協 48巻 238頁 (1953)
献

（2）大地, 志垣, 中村: 日醸協 47巻 512頁 (1952)

（4）伊藤：日醸協, 47巻 137頁 (1952) 